\title{
DEFENDANT'S CONFESSION AT THE MAIN HEARING IN CROATIAN AND COMPARATIVE LAW: JUST ANOTHER PIECE OF EVIDENCE, GUILTY PLEA OR A TACIT AGREEMENT?***
}

Summary: $\quad$ The effects of a defendant's confession are not the same in all legal orders. In civil law systems, confession is usually perceived as an ordinary piece of evidence, while in common law culture it is considered a guilty plea whose truthfulness is not to be questioned by the judge. However, this broad differentiation is not straightforward. In Croatia, if a defendant confesses to a criminal offence punishable by a fine or imprisonment of up to five years at the main hearing and agrees to the sentence proposed by the prosecutor, the trial court is not allowed to impose a sentence higher than the one proposed by the prosecutor. This can motivate tacit agreements and unregulated negotiations between the parties after the main hearing has already begun, and it is unclear if the legislator had such a scenario in mind when enacting this provision. In order to elucidate these problems in a broader perspective, the authors have analysed Croatian, German, Austrian, French, Italian and English law, with an emphasis on the position of the defendant after a confession at the main hearing, the effects of the confession, the role of the court in further proceedings and the victim's rights. After the comparative analysis, the authors presented their opinion on the current legal situation in Croatia, especially Art. 417a (6) and (7) of the Code of Criminal Procedure, together with a proposal for legislative changes.

Keywords:

confession, guilty plea, main hearing, consensual justice, criminal procedure

\footnotetext{
Igor Martinović, PhD, Associate Professor, Faculty of Law, University of Rijeka, Hahlić 6, 51000 Rijeka, Republic of Croatia. E-mail address: imartinovic@pravri.hr. ORCID: https://orcid.org/0000-0002-7648-2443.

** Ivana Radić, PhD, Postdoctoral Researcher, Faculty of Law, University of Split, Domovinskog rata 8, 21000 Split, Republic of Croatia. E-mail address: ivana.radic@pravst.hr. ORCID: https://orcid.org/0000-0003-4946-6437.

** This work has been fully supported by the Croatian Science Foundation under the project "Systematic approach to models of negotiated justice in Croatian criminal procedure" (IP-2019-04-1275).
} 


\section{INTRODUCTION}

In Croatian law, the defendant is traditionally perceived as a possible source of information regarding the facts that are to be determined during the criminal proceedings, which is why it is vital to ensure his/her presence in the trial process. ${ }^{1}$ The right to defence includes the right to remain silent and not to answer any questions regarding the indictment, but the defendant usually chooses to give a testimony and present evidence in his/her favour, or at least to plead guilty or not guilty at the main hearing as the central stage of the criminal proceedings. The content of the plea is vital for the further course of the main hearing, as it determines whether the defendant shall give his/her testimony immediately following the plea or only at the end of the presentation of evidence, unless otherwise requested by the defendant (Art. 417.a (1) and (5) C-CCP). ${ }^{2}$

A guilty plea does not preclude Croatian courts from gathering and presenting other evidence: only if the confession of the defendant is "complete and in accordance with the evidence already gathered", the court shall proceed with the presentation of evidence related to the decision on the sentence (Art. 417.a (4) C-CCP); otherwise, the court shall continue with the presentation of evidence related to the matter of guilt. This rule is difficult to grasp without a broader comparative context, as the effects of confession are fundamentally related to the issue of the purpose of criminal proceedings and the role of the relevant court. The essential question is whether the defendant's guilt should be established by evidence, as in the civil law tradition, or whether the defendant's admission of guilt would lead to the termination of the criminal proceedings and the court is not obligated to further verify it, as in the common law tradition. ${ }^{3}$ This shall be covered in more detail throughout the paper.

Regardless of this divergence between the common law and the civil law model, in the last decades, many European countries have been facing major reforms of the criminal justice systems in a quest for a procedure that would be more consensus-oriented, primarily in order to improve its expedience, but also to strengthen the position of the victim. Some of these reforms are in direct conflict with the guiding ideas of the Continental criminal procedure, but they also fail to implement the ideas underlying the concept of consensual justice. Hence, they remain trapped between the two concepts of criminal justice while retaining the shortcomings of both of them. A prime example is found in Art. 417.a (6) and (7) C-CCP, which fails to ensure an exhaustive, court-controlled presentation of evidence and to improve the position of the victim. This provision shall be analysed and compared to the legislative regimes in other countries.

In addition to Croatia, our research also includes Germany, as the exemplary civil law role model, Austria, which shares a common legal heritage with Croatia, France, as a cradle of the "mixed" criminal procedure, Italy, as an example of a civil law system which has adopted a great deal of common law solutions, and England, as a representative of the common law

1 Tomašević, G., Kazneno procesno pravo, Opći dio: Temeljni pojmovi, Pravni fakultet Sveučilišta u Splitu, Split, 2011 , pp. 136.

2 Croatian Code of Criminal Procedure (C-CCP), Official Gazette, No. 152/08, 76/09, 80/11, 91/12 - Decision and Ruling of the Constitutional Court of the Republic of Croatia, 143/12, 56/13, 145/13, 152/14, 70/17, and 126/19.

3 Specer, J. R., Evidence, in European Criminal Procedures (eds. Delmas_marty, M., Spencer, J.R.), Cambridge University Press, Cambridge, 2006, pp. 594-595. 
tradition. The primary aim is to explore the effects of a guilty plea, i.e. confession, at the main hearing together with the impact of tacit agreements and sentencing proposals of the prosecution on the sentencing powers of the court and the position of victim. This is followed with a proposal for legislative amendments.

\section{CROATIA: BETWEEN THE PRINCIPLE OF SUBSTANTIVE TRUTH AND ITS NEGATION}

The duty of the court to establish the relevant facts in the criminal proceedings, known as the principle of substantive truth (načelo materijalne istine), was expressly stated in the Yugoslav and Croatian Code of Criminal Procedure (Zakon o krivičnom postupku) before 1998, but the statutory law has not addressed it ever since. Some notable Croatian authors have condemned this principle as a "normative disguise for raw state power" and a remnant of totalitarianism, ${ }^{4}$ while others have supported it as a backbone of the most renowned Continental criminal procedures (e. g. French, German and Austrian) ${ }^{5}$ and emphasised that it is still an integral part of the Croatian criminal proceedings. ${ }^{6}$

The latter view is well-grounded as the current Croatian CCP (Zakon o kaznenom postupku) contains a great number of rules which clearly express the duty of the court to establish the facts ex officio in the criminal proceedings. One of the notable examples thereof is Art. 417.a (3) and (4) which states that a confession of the defendant at the main hearing "does not release the court from the duty to present other evidence". Interestingly, this provision does not only proclaim the duty of the court to inspect truthfulness of the defendant's confession at the main hearing, but it also implicitly states the duty of the court to present evidence, i.e. to establish the facts of the case. This proves that the Croatian criminal procedure is still a part of the civil law tradition, which does not regard criminal trial as a "competition" (or a dialogue) between the parties, but as a judge-dominated procedure whose purpose is to establish the relevant facts and apply substantive law. The C-CCP determines its own purpose accordingly: it "lays down rules to ensure that no innocent person is convicted and that the perpetrator of a criminal offence is sentenced under the conditions provided by law and on the basis of lawfully conducted proceedings before a competent court" (Art. 1).

The duty of the court to "present other evidence" when the defendant makes a confession at the main hearing does not only encompass evidence which is significant for the issue of his/her guilt, but also the evidence which is relevant for sentencing. That evidence shall be presented even where the defendant's confession at the main hearing is "complete and in accordance with the previously obtained evidence" (Art. 417.a (3) and (4)). In some cases, however, the court's powers and duties to determine the sentence are completely handed over to the prosecutor. This applies to the cases in which criminal proceedings are conducted for a criminal offence punishable by a fine or imprisonment of up to five years, provided that the

4 Krapac, D. i suradnici, Kazneno procesno pravo, Prva knjiga institucije, Narodne novine, Zagreb, 2015, pp. 85-86.

5 Đurđević, Rekonstrukcija, judicijalizacija, konstitucionalizacija, europeizacija hrvatskog kaznenog postupka V. novelom ZKP/08: prvi dio?, HLJKPP 2/2013, 335-342. 
defendant has pleaded guilty and agreed to the sentence proposed by the prosecutor (Art. 417.a (6)). Under these conditions, "the court may not impose another type of sentence or other measure prescribed by criminal law, or a higher sentence than the one proposed" by the prosecutor (Art. 417.a (7)).

The purpose of these provisions is straightforward: the legislator aimed to expedite the criminal proceedings by motivating the defendant to confess in exchange for a relatively lenient sentence. This legislative solution has established itself in the Croatian law in 1998 as an important feature of the summary procedure, surviving various regulatory regimes in the meantime, including the very abolishment of this type of procedure. ${ }^{7}$ It has been applied by the Croatian courts, including the Supreme Court. ${ }^{8}$ Yet, its very existence is surprising from a comparative perspective as well as from the standpoint of the basic principles of the Croatian criminal procedure. Personal liberty is one of the fundamental human rights enshrined in the Croatian Constitution" and its deprivation is allowed only "when specified by law, upon which a court shall decide" (Art. 2. (2)). Bearing in mind the supremacy of the Constitution in relation to all other legal sources, no statutory provision should be allowed to deprive the court of its power to decide on the sentencing, at least in cases where the deprivation of liberty is involved. While it could be argued that these statutory provisions do not deprive the defendant of his/her personal liberty any more than usually, as the court is still allowed to impose a milder sentence than the one proposed by the prosecutor, they strip the court of its power to deliver a harsher sentence if it considers the proposed one to be unduly lenient. On the other hand, the Constitution states that "courts shall administer justice according to the Constitution, law, international treaties and other valid sources of law" (Art. 115 (3)) and not according to some informal arrangements between the parties which obstruct the courts in fulfilling their constitutional duties. A further problem is the disregard for the victim's rights and interests in this sort of procedure ${ }^{10}$ as he/she is not allowed to reject the proposed sentence or at least formally express his/her opinion on its appropriateness.

\section{GERMANY: ON THE CROSSROADS OF PRINCIPLES AND REALITY}

The German system of criminal justice is characterised by a principle which is very common in the civil law tradition, but nevertheless needs to be mentioned in a comparative study as it might be unfamiliar to lawyers from other legal systems. It is the Untersuchungsgrundsatz (also known as Amtsermittlungsgrundsatz, Inquisitionsmaxime, Amtsermittlungspflicht or Amtsaufklärungspflicht) which is regulated in section 244 (2) of the Code of Criminal Procedure

7 In its current form, Art. 417.a (6) and (7) is enacted by Art. 200 of the Act on Amendments to CCP, Official Gazette No. 143/2013. Ratio legis of the legislative proposal was to meet the requirements from the decision of the Constitutional Court that aimed to "harmonise the normative structure of the entire criminal procedure", which has caused the abolishment of the summary procedure as a special type of procedure, followed by the transition of some of its former provisions to various other articles of the C-CCP, including Art. 417.a. See: Draft of the Act on the Amendments to the Code of Criminal Procedure, Ministry of Justice, November 2013, Zagreb, pp. 161.

8 See, e.g., VSRH, I Kžm-31/16.

9 Croatian Constitution, Official Gazette, No. 56/1990, 135/1997, 113/2000, 28/2001, 76/2010, 5/2014. 
(Strafprozeßordnung - StPO) ${ }^{11}$ : in order to establish the truth, the court shall, by virtue of office (ex officio), extend the gathering of evidence to all facts and means of proof which are relevant to the decision. In other words, the duty of the court is to establish the truth (Erforschung der Wahrheit). It is "the central concern" of the criminal procedure. ${ }^{12}$ In order to establish the truth, the court has a power and duty to act independently; this means, inter alia, that the court is not bound by the parties' submissions when applying the criminal law (section 155 (2) of the Code of Criminal Procedure).

Legal effects of the defendant's confession are thoroughly marked by this principle. To be more specific, confession does not remove the duty of the court to establish all the relevant facts of the case. Such confession is largely different from a guilty plea under the common law because a defendant who makes a confession is not necessarily convicted. The remainder of the main hearing does not only serve to determine the sentence, but also to establish if the confession corresponds to what had actually happened. This means that a confession is essentially a piece of evidence like any other; although it does typically expedite the main hearing, particularly when it is factually substantiated, the Untersuchungsgrundsatz "shall not be sacrificed in the interest of a simple and expedient settlement of the proceedings". ${ }^{13}$

Before analysing the consequences of making a confession, a definition of this term shall be given from the perspective of the German law. Confession (Geständnis) is any admission of facts by the defendant with regard to the offence of which he/she is charged, which may be relevant for determining guilt (Schuldfrage) or the sanctions (Rechtsfolgenentscheidung), regardless of whether these facts incriminate or exonerate the defendant. ${ }^{14}$ When determining guilt and sanctions, a confession is the object of free judicial assessment of evidence, which means that the trial court must be convinced of its accuracy if the conviction is to be based on it. ${ }^{15}$ Restricting the reasoning of the conviction to the fact that the accused had confessed is therefore not acceptable. Rather, according to the established case-law, the court must examine whether a confession is coherent and whether there are any reasons to doubt its credibility with regard to the other available evidence. ${ }^{16}$ For instance, if the defendant incriminated any third parties in his confession, the court shall consider if the confession was possibly motivated by the defendant's hope to gain advantages. A "blanket" confession, i.e. a merely formal confession in which the defendant does not disclose any factual circumstances, cannot form the sole basis for the judgment, but even if a confession is thoroughly substantiated, it is not sufficient if the defendant's recollection ability raises suspicions about the accuracy of his confession. Conviction based solely on the confession is, however, possible, but only when the facts of the case are simple enough and the charge is sufficiently specific. ${ }^{17}$

\footnotetext{
11 Strafprozeßordnung (StPO) as published on 7 April 1987 (Official Gazette I, p. 1074, 1319), last amended by Article 49 of the Act from 21 December 2020 (Official Gazette I, p. 3096)

12 Krehl, Karlsruher Kommentar zur Strafprozessordnung: StPO, C.H. BECK, 8. Aufl., 2019, StPO § 244 Rn. 28.

13 KK-StPO/Ott, Karlsruher Kommentar/StPO, C. H. BECK, 8. Aufl. 2019, StPO § 261 Rn. 92.

14 KK-StPO/Diemer, 8. Aufl. 2019, StPO § 254 Rn. 3; BeckOK StPO/Ganter, 38. Ed. 1.10.2020, StPO § 254 Rn. 6; BGH MDR 1977, 984 [H.]; RGSt 54, 126 (127) Beck Beck'scher Online-Kommentare.

15 Cf. BGH StV 1999, 410.

16 See BGH NStZ 2014, 53 and 170. 
In spite of the inquisitorial powers and duties of the German criminal courts, the Code of Criminal Procedure was amended in 2009 in order to allow agreements between the parties and the court. The legislator introduced the "negotiated agreement" in order to formalise negotiations which, in reality, had already existed in German criminal proceedings, but were informal in nature. The newly introduced section 257c (Verständigung zwischen Gericht und Verfahrensbeteiligten) does not, however, represent a plea bargain in the strict sense as the court still plays a very prominent role in the proceedings: the whole process of reaching an agreement begins with its announcement as to what the agreement could possibly include. The agreement shall come into existence if both the defendant and the public prosecutor's office agree to the court's proposal, wherein defendant's confession must be an integral part of the agreement. The agreement may only be reached with regard to the sanctions (Rechtsfolgen) which can be imposed by the judgment, to other procedural measures and to the conduct of the parties during the proceedings. As the duty of the court to establish the truth is prescribed by the law even where an agreement is reached, the guilty judgement (Schuldspruch) may not be the subject of the agreement. The court shall cease to be bound by the agreement if the relevant circumstances have been overlooked or if the defendant's conduct in the proceedings does not correspond to the conduct upon which the proposal had been based; in such cases, the confession may not be used.

The recently introduced section 257c has been a subject of fervent criticism. Many authors believe that the German system of criminal justice should remain inherently opposed to any sort of negotiations between the parties. The "negotiated agreement" is regarded as a fundamental change of the Code of Criminal Procedure, which is incompatible with the duty of the court to establish the relevant facts. Although the Untersuchungsgrundsatz is still formally valid, the very sense of the agreement is to avoid further inquiries, which means that the duty of the court to establish facts ex officio is still valid only in a rather vague sense. The reference to this principle in section $257 \mathrm{c}$ is regarded by some as nothing more than a "lip service". ${ }^{18}$ Another line of criticism concerns the right against self-incrimination (nemo tenetur), which is jeopardised if any pressure is exerted on the defendant to make a confession. Having in mind that the refusal to make a "deal" carries great risks for the defendant, as a much higher sentence might be imposed, the nemo tenetur principle is certainly brought into question. Moreover, the principle of openness of the main hearing is also sometimes considered to be violated by negotiations between the parties. ${ }^{19}$

Notwithstanding the justified criticism of the recent legislative changes, it should be emphasised that the German law does not provide for a classic plea bargain which would directly and invariably prevent the court from determining the relevant facts after the defendant's confession. In fact, a confession is often a key piece of evidence which considerably expedites the main hearing, but it is not up to the parties to decide if the main hearing before the court is to be conducted or not and it is not up to the court to decide if it will exercise its power to establish the relevant facts or not. There is a duty, and not only a power, of the court to exercise its powers in order to establish the facts and apply the law, both in ordinary proceedings and in cases when there is a confession induced by negotiations. The court also

18 Meyer-Goßner, L., Schmitt, Strafprozessordnung: Gerichtsverfassungsgesetz, Nebengesetze und ergänzende Bestimmungen. 57. Aufl. 2014, § 257c Rn 3. 
decides independently on the sentencing, without being obliged to follow any sanction-related suggestions from the prosecutor, regardless if these were self-induced or a result of an off-therecord agreement between the parties. Even when confronted with a penalty order submission (Strafbefehlsantrag) by a state prosecutor, which is a means of summary criminal proceedings for minor offences, the court does not have to comply with the submission: if the court has reservations about deciding the case without a main hearing or if it wishes to deviate from the state prosecutor's legal assessment of the case or to impose a legal consequence other than the requested one, it shall not issue a penalty order. Instead, the court shall proceed to the main hearing (section 408 (3) of the Code of Criminal Procedure).

\section{AUSTRIA: THE OLD-SCHOOL CIVIL LAW APPROACH TO CONFESSION}

The Untersuchungsgrundsatz is a central tenet of the Austrian criminal procedure. As laid down in section 3 (1) of the Code of Criminal Procedure (Strafprozeßordnung - StPO) ${ }^{20}$, criminal police, public prosecutor's office and court have a duty to investigate the truth and clarify all facts which are of importance for the legal assessment (Beurteilung) of the offence and the defendant. This principle is even more prominent than in the German law as the very idea of negotiations between the parties is dismissed because of it. Although negotiations between the parties or between the defendant and the court are not expressly forbidden by the Austrian statutory law, the Supreme Court of Austria nevertheless finds any such negotiations - except for those held in accordance with the diversion proceedings, which are legally sanctioned - to be in contradiction with the duty of the court to establish the substantive truth (Erforschung der materiellen Wahreheit). ${ }^{21}$ Austrian statutory texts, while not expressly prohibitive to the very idea of negotiations, provide considerable support for the standpoint of the court. Section 164 (4) of the Code of Criminal Procedure outlaws any promises (Versprechungen) which might be used to induce the defendant to confess or provide other information. Moreover, section 52 of the Code of Conduct for Courts of First and Second Instance (Geschäftsordnung für die Gerichte I. und II. Instanz) declares that the judge is prohibited from giving statements about the probable outcome of the proceedings outside of the hearing and that he/she should refrain from commenting on the likely content of the decision during the hearing.

Standing firm to the Untersuchungsgrundsatz, Austria remains loyal to the traditional civil law approach to criminal justice, in which the court is not perceived as an impartial referee, but as an active subject whose duty is to investigate all the relevant facts of the case and apply the law. In such a legal context, it is understandable that the confession of the defendant does not automatically imply a conviction as it does not discharge the court from the aforementioned duty. This means that even an exhaustive confession must be examined by the court in order to check its truthfulness. In other words, the courts and other relevant authorities (police and state prosecutor) are obliged to fully elucidate the relevant facts even if the defendant gives a confession, which is thus just another object of free judicial assessment of evidence. ${ }^{22}$

\footnotetext{
20 Strafprozessordnung (StPO) 1975, BGBl. Nr. 631/1975 (WV), latest amendment BGBl. I Nr. 24/2020.

21 OGH 11 Os 77/04. 


\section{ITALY: AN ELABORATE SYSTEM OF NEGOTIATIONS}

Italian Code of Criminal Procedure (Codice di procedura penale,I-CCP) entered into force in $1989^{23}$ and has been thoroughly amended since then by a variety of different statutes. The adoption of the Code was considered revolutionary because Italy was the first traditionally inquisitorial judicial system to introduce various adversarial principles into the criminal procedure. ${ }^{24}$ An important feature of the Italian system is that the prosecutor is obligated to prosecute whenever there is sufficient evidence to charge the defendant. ${ }^{25}$ In Italian criminal procedure, evidence must be presented orally, in a public hearing, before the judge who then has to decide whether the defendant is guilty or not guilty. ${ }^{26}$ Any evidence that was collected or presented during the preliminary phase (investigation) may not form part of the case file, which serves as the basis for the judgment. ${ }^{27}$ The burden of proof is on the prosecutor. The defendant has the right to remain silent, he/she is not obligated to disclose anything regarding the charges and he/she is not obligated to provide any exculpatory evidence. If the prosecutor fails to prove the defendant's guilt beyond any reasonable doubt, the judge must acquit the defendant. ${ }^{28}$ The defendant and the private parties can only be heard in trial at their own request. The Italian Constitutional Court considered the requirements of the defendant's consent to be constitutional based on the assumption that the defendants may not be obliged to give testimony against themselves, nor can they be coercively brought to the court for the purposes of their examination. ${ }^{29}$

The defendant can be examined at the trial under the same terms that apply for the examination of witnesses. The hearing of the defendant usually takes place at the end of the evidence gathering procedure so that the defendant can properly assess whether to give oral evidence or not. ${ }^{30}$ Evidence gathering at the main hearing usually begins with the evidence presented by the public prosecutor and continues with the evidence presented by the other

23 Codice di procedura penale, Aggiornato al D.L. 17 marzo 2020, n. 18.

24 Frommann, M., Regulating Plea-Bargainig in Germany: Can the Italian Approach Serve as a Model to the Guarantee the Independence of German Judges?, Hanse Law Review Comparative Law, vol. 5, No. 1, 2009, p. 210.

25 In Italy, the principle of legality of criminal prosecution is set as a constitutional principle in Art. 112 of the Constitution. See: Krstulović, A., Nagodbe stranaka u suvremenom kaznenom postupku, Hrvatsko udruženje za kaznene znanosti i praksu-MUP RH, Zagreb, 2007, p. 75.

26 The judge makes his/her decision based on the case file that contains only the evidence that can be used by the judge at the end of the trial (Art. 431 I-CCP). See more: Perrodet, A., The Italian System, in European Criminal Procedures (eds. Delmas-Marty, M., Spencer, J.R.), Cambridge University Press, Cambridge, 2006, p. 368-369.

27 There are two important exceptions to this rule. Firstly, this does not refer to the activity which cannot be repeated at the trial and, secondly, when the defendant gives his/her consent, written submissions can be inserted in the case file and used by the judge (Art. 493 (3) I-CCP). Ruggieri, F., Marcolini, S., Italy in Toward a Prosecutor for European Union, volume: 1: A comparative Analysis (ed. Katalin Ligeti), London: Hart Publishing, 2013., 395. Ibid., pp. 397.

It should be noted that out-of-court statements of the defendant (statements that he/she has made in the pre-trial phase) can be admitted at the trial in cases when the defendant does not consent to the trial examination or is not present at hearing. Ruggeri, S., Audi Alteram Partem in Criminal Proceedings, Towards a Participatory Understanding of Criminal Justice in Europe and Latin America, Springer, 2017, p. 77-78. 
parties (Art. 498) ${ }^{31}$ I-CCP states that the court shall evaluate evidence specifying the obtained results and the criteria adopted in the rationale of the judgment (Art. 192 (1) I-CCP).

In Giuidizio Direttissimo, when the defendant during the questioning makes a full confession to the public prosecutor, the public prosecutor can decide to summon that defendant to appear at the hearing in front of a judge within the period of fifteen days from the day of entering of the offence in the register of notitiae criminis. The same time limit is valid for the defendants held in pre-trial detention (Art. 449 (5) I-CCP). This type of measure shows that in Italy the acknowledgment of guilt does not necessarily imply a guilty plea. In this situation, only the investigation is waived but the defendant's case is promptly transferred to the court. ${ }^{32}$

One more diversion measure in Italy that can be connected with a guilty plea is the patteggiamento: application of the penalty at the request of the parties (Art. 444-448 I-CCP). Patteggiamento is considered neither a guilty judgement ${ }^{33}$ nor a plea bargain. It is a request that can be made during a preliminary hearing (Art. 446 (1) I-CCP) or in exceptional cases during the trial (Art. 448 (1) I-CPP) ${ }^{34}$ by the prosecutor and the defendant jointly or separately, but in that case only with the consent of the other party (that did not make the request). Request can be made only in cases of criminal offence where the specific maximum sentence does not exceed 5 years of imprisonment (Art. 444 (1) I-CCP). Some criminal offences are excluded from this, e.g. organised crime, sex-related criminal offences and cases of habitual and repeated offenders. The request must be submitted to the judge and must contain the type and measure of the sanction and the circumstances that should be applied in that specific case. ${ }^{35}$

When the judge receives the request, he/she will decide on the admissibility of the agreement based on the case file in several steps. First, he/she must check if there are any grounds for the acquittal according to Art. 129 I-CCP. ${ }^{36}$ The judge can accept or reject the parties' agreement. Before the judge decides, he/she must verify whether the legal qualification of the criminal offence is correct and whether the proposed punishment is adequate taking under account all mitigating and aggravating circumstances of the case. It is important to note that the judge not only controls the legality of the proposed sentence but also examines whether it can fulfil the general and special purpose of sanctioning (Art. 444(2) I-CCP). The judge can reject the agreement if he/she finds that the balancing of incriminating and exculpatory indicia is conducted incorrectly. ${ }^{37}$ The judge can request from the defendant to appear in order to verify the

31 Perrodet, A., op. cit. Note 26, pp. 381-382.

32 Coscas-Williams, B., Alberstain, M.: A Patchwork of doors: accelerated proceedings in continental criminal justice systems, New Criminal Law Review, vol. 22., No. 4., fall 2019, p. 610.

33 This institution does not involve any admission of guilt because that would violate the presumption of innocence. Ibid., pp. 605 . The scholars`opinion is that patteggiamento does not allow for a conviction without the judge having previously established the defendant`s guilt. The Constitutional Court also confirmed that in patteggiammento there is an obligation to establish guilt, but that requirement was limited by the nature of this simplified procedure. Frommann, M., op. cit. Note 24, pp. 212-214.

Coscas-Williams, B., Alberstain, M., op. cit. Note 32, pp. 605. This is considered to be an exception because the main rule is that the request must be presented to the judge at the preliminary hearing or until the initiation of the trial in a specific procedure (Art. 446 (1) I-CCP). Law amendment from 2003 (Law no. 134 from 2003) formed a transitional regime in which it was stated that the request could also be made during the main hearing, and the Italian Court of Cassation decided that the Law refers only to "the first instance main hearing". See: Krstulović, A., op. cit. Note 25, pp. 79 (note 219). 
voluntariness of his/her request or consent (Art. 446(5) I-CCP). If the judge accepts the agreement of the parties, he/she is bound by the sentence that was agreed by the parties and in his/ her decision explain the reasons why he/she accepted the agreement. ${ }^{38}$ If the judge rejects the agreement, the file is sent back to the ordinary proceedings. ${ }^{39}$

In the Italian case law, there were different opinions about the role of the court in patteggiamento. In 1990, the Italian Constitutional Court confirmed that the role of the judge is not simply to check and confirm the parties' agreement but that he/she has the authority to control not only the formal but also the material preconditions of the agreements and whether the proposed sanction is in accordance with the facts of the case and the purpose of sanctioning. If the court finds that the proposed sanction is not appropriate, it can reject the agreement. ${ }^{40}$ If a party considers that the proposed sentence is not acceptable, it can reject it. If the defendant does so, he does not have to give any reasoning for his decision, while in the opposite situation the prosecution must provide the judge with the reasons why they refused the agreement. ${ }^{41}$ If the defendant makes a request that the prosecutor disapproves of or that is rejected by the preliminary investigation judge, prior to the opening of the first instance trial, the defendant can submit his/her request again and the court shall immediately deliver the judgment, if it considers that the request is well-founded. The request cannot be further submitted with another court (Art. 448(1) I-CCP). If the judge believes that the prosecutor refused the defendant's request on unjustified grounds, he/she will follow the same procedure even after the closure of the first instance trial or in the remedy trial. This means that in those situations, the sentencing does not occur when anticipated but subsequently, i.e. after the closure of the first instance trial or remedy trial (Art. 448(1) I-CCP). ${ }^{42}$ The prosecutor has the right to appeal that decision (Art. 448(2) I-CCP). The procedure of patteggiamento is closed for public and the legislation does not provide for the participation of the victim in the agreement.

\section{FRANCE: A TYPICAL “MIXED” SYSTEM}

In France, criminal procedure is regulated by the Code de procédure pénale ${ }^{43}$ (Code of Criminal Procedure; F-CCP) that was adopted in 1958 by an ordinance, as a redrafting of the $\mathrm{Na-}$ poleonic Code d'instruction criminelle from $1808 .{ }^{44}$ The current French criminal procedure is considered a mixed system, including the adversarial principle that is enshrined in the introductory article of the F-CCP. The French criminal procedure has many accusatorial features,

38 Frommann, M., op. cit. note 24, pp. 212.

39 Coscas-Williams, B., Alberstain, M., op. cit. Note 32, pp. 606.

40 Coscas-Williams, B., Alberstain, M., op. cit. Note 32, pp. 605. Krstulović, A., op. cit. Note 25, pp. 83, 89.

41 Krstulović, A., op. cit. Note 25, pp. 80.

42 Ibid., pp. 80.

43 Code de procédure pénale, Version en vigueur au 08 décembre 2020, Code de procédure pénale in French: https://www. legifrance.gouv.fr/codes/texte_lc/LEGITEXT000006071154/2021-01-08/.

44 Tricot, J., France in Toward a Prosecutor for the European Union, A comparative Analysis (ed. Katalin Ligeti), London: Hart Publishing, vol. 1, 2013, pp. 222. 
but the inquisitorial tradition can also be noticed. ${ }^{45}$ The principle of opportunity is the basis of criminal prosecution in France. ${ }^{46}$ In cases when the defendant is committed to the trial, ${ }^{47}$ he/she must be questioned by a judge before the witnesses are heard (Art. 272, 328, ${ }^{48} 442$ and 536 F-CCP). The defendant's attorney, the prosecution, and the victim all have the right to question the defendant and other witnesses at the trial. Since 2000, they may do this directly by requesting the president of the court to allow them to speak (Art. 312 and 442-1 F-CCP). ${ }^{49}$ But the judge still leads the examination of the case on the basis of having read the case file, ${ }^{50}$ which is a typical inquisitorial feature. The trial judge asks the questions, leads and steers the hearing, and determines the value of the evidence submitted in each case. ${ }^{51}$ Regarding the evaluation of evidence in France, the basic rule is that a criminal offence can be established by any evidence and the judge is free to evaluate these evidence as he/she wishes. ${ }^{52} \mathrm{~F}-\mathrm{CPP}$ in Art. 428 states that "confessions, as any other type of evidence, are left to the free evaluation of the judges". ${ }^{53}$ This means that even the confession from the defendant at the main hearing must be evaluated by the judge as any other evidence.

In order to reduce the growing caseload of criminal courts, F-CPP implemented a wide range of alternative procedures. ${ }^{54}$ One of these new measures requires the acknowledgment of guilt from the defendant, comparution sur reconnaissance préalable de culpabilité, otherwise known as CRPC. CRPC was introduced in F-CCP in 2004 and is often considered to be inspired by the US plea bargain. CRPC applies to criminal offences that impose a prison sentence of less than 10 years ${ }^{55}$ and it can be proposed by the prosecutor or the defendant or his/her attorney. The sentence proposed to the defendant may not exceed one-year imprisonment or half of the maximum sentence for that criminal offence. First the prosecutor, defendant and his/her attorney have a brief discussion about the facts of the case. The attorney must be present during the defendant's confession and the plea bargain from the prosecutor. ${ }^{56}$ The defendant has ten days to decide whether to accept or reject the plea bargain made by the prosecutor. If the

45 Hodgson, J., Guilty Pleas and the Changing Role of the Prosecutor in French Criminal Justice, Warwick School of Law Research Paper, No. 2010/15, pp. 9.

46 Art. 40. F-CCP. Krstulović, A., op. cit. Note 25, pp. 106.

47 Currently, a full trial based on a lengthy phase of hearing in the adversarial method and a long investigation in the inquisitorial system is considered the option of last resort in France. Coscas-Williams, B., Alberstein M., A., op. cit. Note 32, pp. 615.

48 Art. 328. F-CCP states that the judge must inform the accused about his/her right during the hearing including the right “... to provide the answers to the questions or to remain silent", after which the judge questions the defendant and takes his/her deposition. (Modifié par LOI n²014-535 du 27 mai 2014 - art. 8).

49 Dervieux, V.,The French system, in European Criminal Procedures, (eds. Delmas-Marty, M., Spencer, J.R.) Cambridge University Press, 2006, pp. 253.

50 Hodgson, J., op. cit. Note 45, pp. 9.

51 Coscas-Williams, B., Alberstein M., op. cit. Note 32, pp. 597.

52 Dervieux, V., op. cit. Note 49, pp. 263.

53 Art. 428 F-CPP: "L’aveu, comme tout élément de preuve, est laissé à la libre appréciation des juges." (Modifié par Loi 93-1013 1993-08-24 art. 28 JORF 25 août 1993 en vigueur le 2 septembre 1993).

55 This was modified in 2011. Previously, these proceedings only referred to criminal offences imposing a fine or a prison sentence of 5 years or less. The CRPC also excludes certain grave criminal offences such as rape and murder.

56 Representation by an attorney during CRPC is mandatory. In practice, defendants who cannot afford an attorney but do not qualify for legal aid or those who do not wish to pay for an attorney are excluded from the CRPC. See: Soubise, L., Guilty Pleas in an Inquisitorial Setting - an Empirical Study of France (September 2018). Journal of Law and Society, Cardiff University Law School, Vol. 45, Issue 3, 2018, p. 417. 
defendant refuses to plead guilty or rejects the plea bargain, his/her case will be sent to trial. If he/she pleads guilty and accepts the plea bargain from the prosecutor, the procedure moves to the second phase referred to as homologation (l'homologation), where the judge must confirm or reject the plea bargain during a public hearing. During homologation, the court has the power to examine the procedural truth. ${ }^{57}$ This means that if the judge has any doubts about the case or thinks that the proposed sentence is not proportional to the circumstances of the case, he/she will reject the proposal and send the case to trial. It is important to notice that the court has the power to accept or to reject the sentence proposal, but he has no power to amend it. ${ }^{58}$ When the plea bargain is not accepted, the parties cannot resort to it later in the trial (Art. 485-14 F-CCP). The victim is informed about the procedure, he/she can appear before the court with an attorney, become a civil party and demand compensation (Art. 495-13 F-CCP).

CRPC was introduced in France with the aim to expedite the disposal of cases, but its use in practice still remains relatively low, especially in comparison to a guilty plea in the UK. In England and Wales, over $78 \%$ of defendants prosecuted by the CPS at the magistrates' court and over $70 \%$ at the Crown Court pleaded guilty in 2016/17, while in France CRPC accounted for merely $6.4 \%$ of prosecutable cases in $2016 . .^{59}$

\section{ENGLAND AND WALES: CONTRACTUAL ATTITUDES TOWARDS THE GUILTY PLEA}

As opposed to a great number of civil law jurisdictions, including Germany and Austria with their Legalitätsprinzip, the prosecution is not mandatory in most common law jurisdiction, which means that the prosecutor is not legally required to press charges even though there is enough evidence to support indictment. The Code for Crown Prosecutors, which is issued by the Director of Public Prosecutions, sets out the general principles Crown Prosecutors should abide by when making decisions about the cases and states that "in every case where there is sufficient evidence to justify a prosecution or to offer an out-of-court disposal, prosecutors must go on to consider whether a prosecution is required in the public interest" (section 4.9). Moreover, there is no duty of the court to establish the facts ex officio, which is, on the other hand, the central tenet of the German and Austrian criminal law. This inherent flexibility produces incentives for informal plea deals, which are not viewed as something that would jeopardise the very foundations of criminal justice.

57 In practice, this validation from the judge has often been described as "quick and artificial" because the judges often just confirm facts that have been already established. Ibid., pp. 414.

58 Coscas-Williams, B., Alberstain M., op. cit. Note 32, pp. 600-604. See also: Hodgson, J., op. cit. Note 45, pp. 11-14.

59 In French practice, CRPC procedure usually takes around 5 months and is typically used for offences like driving under influence without a licence, domestic violence (minor assault and harassments) and minor frauds and thefts. It is interesting to note that the defendants in CRPC usually had prior convictions. Some authors believe that the entire procedure is in the hands of the prosecutors who are under a considerable pressure to prosecute the case quickly and efficiently, which then results in bureaucratisation of prosecutorial decisions. In many cases, the prosecutors make their own decisions by using standardised tables and instructions, with no reflection on the individual elements of the case. See more: Soubise, L., op. cit. Note 56, pp. 408414. 
Having in mind that the court is not required to establish "substantive" truth in the criminal proceedings, the defendant`s guilty plea means that he/she accepts the assertion that he/ she has committed the incriminating offence. Both in common and in civil law jurisdictions, the purpose of the trial (or main hearing) is to address the accusations brought by the prosecution, but in common law jurisdictions the trial is not considered to be a necessary part of the criminal proceedings: it is up to the defendant to decide whether he/she will exercise the right to a trial or waive it by pleading guilty.

Acceptance of the model in which the defendant loses the right to a trial by pleading guilty has a profound effect on the powers and duties of the court following a guilty plea. The most important thing to emphasise, at least from the civil law perspective, is the fact that the court may not examine whether the plea is grounded in reality ("substantive" truth). In the magistrates' court, if the defendant pleads guilty and the court is satisfied that the plea represents a clear acknowledgement of guilt, the court may convict the defendant without collecting evidence (The Criminal Procedure Rules 2020, section 24.7). Similarly, in the Crown Court, if the defendant pleads guilty to an offence and the court is satisfied that the plea represents a clear acknowledgement of guilt, the court is not required to collect evidence unless it needs to determine the facts for the sentencing phase (The Criminal Procedure Rules 2020, section 25.4). Acknowledgement of guilt is considered to be "clear" when it is equivocal. If it is ambiguous, e.g. when the defendant "qualifies what purports to be a guilty plea with words suggesting that he/she is really putting forward a defence", the court must try to resolve the ambiguity. If it remains unequivocal, the court must reject it and hear evidence. ${ }^{60}$

A guilty plea in the magistrates' court may be withdrawn by the defendant before the sentencing. His/her motion to withdraw a guilty plea must explain why it would be unjust not to allow the defendant to withdraw the guilty plea, identify any witness or other proposed evidence and say whether the defendant waives the legal professional privilege (The Criminal Procedure Rules 2020, section 24.10). In the Crown Court, a party may vacate a guilty plea before the final disposal of the case. The motion must explain why it would be unjust for the guilty plea to remain unchanged, indicate the evidence the applicant wishes to present, identify any proposed witnesses and indicate whether the legal professional privilege is waived (The Criminal Procedure Rules 2020, section 25.5). Having in mind that the right to withdraw or vacate a guilty plea is very restricted, it is not surprising that the right to appeal the guilty plea convictions is even more limited. In case of a guilty plea, the appeal from the magistrates' court to the Crown Court is allowed only against the sentence (Magistrates' Courts Act, section 108), unless the magistrates' court treated an equivocal plea as a guilty plea, in which case the defendant may appeal against the conviction as well. Appeal from the Crown Court is heard by the Court of Appeal Criminal Division, which shall allow an appeal against conviction if they think that the conviction is unsafe and shall dismiss such an appeal in any other case (Criminal Appeal Act 1968, section 2). Although the Court of Appeal has an "almost unlimited power to declare any conviction unsafe", there is nevertheless "reluctance to allow appeals against guilty plea convictions"; in nearly all cases, "defendants can only appeal on the basis that their pleas were involuntary or equivocal". ${ }^{61}$ The reluctance to allow appeals includes

60 Blackstone's Criminal Practice 2018, D.22.4.; McPeake, Criminal Litigation and Sentencing, 23rd Edition, 2011, p. 108.

61 Richard Nobles \& David Schiff, The Supervision of Guilty Pleas by the Court of Appeal of England and Wales - Workable Relationships and Tragic Choices, Criminal Law Forum, volume 31, 2020, p. 513-552. 
cases where the defendants "may have succumbed to the pressure to plead guilty arising from sentence discounts" as well as appeals "on the basis of new evidence that throws doubt on defendants' guilt". ${ }^{62}$

To conclude, a guilty plea is generally precluded from any subsequent control as to its truthfulness, either by a trial court or by an appellate court. The reason behind this is that an innocent defendant should not have admitted to the facts which are not true in the first place. As far as he/she voluntarily waived his/her right to a trial, he/she cannot argue that the act of waiving was unjust. Such "contractual justification" is opposed by a considerable number of authors, some of which are pointing out that it "ignores the crucial difference between civil and criminal proceedings. The community as a whole normally has no independent interest in establishing whether a civil defendant did or did not commit the incriminating acts. False convictions, by contrast, impact the community by removing attention from those actually responsible for crimes, and by wasting resources by punishing and rehabilitating the wrong persons." 63

As well as causing relinquishment of the right to a trial, a guilty plea has a profound effect on sentencing. The Definite Guideline issued by the Sentencing Council for England and Wales, in accordance with the Coroners and Justice Act, expressly states that its purpose "is to encourage those who are going to plead guilty to do so as early in the court process as possible". Guilty plea produces a sentence reduction at the first stage of the proceedings as well as at a later stage, but while a guilty plea indicated at the first stage produces a reduction of one-third, the reduction is made to a maximum of one-tenth when the guilty plea is first indicated to the court on the first day of trial. But even when the defendant pleads guilty at an early stage, the sentencing powers still remain in the hands of the court, notwithstanding the fact of whether the guilty plea was based on an agreement between the parties or on the defendant's own initiative.

As a conclusion based on the comparative overview: in European countries based on the civil law tradition (German, France, Austria), the guilt of the defendant should always be established by evidence and the judge remains obligated to establish the material truth even in situations when the defendant, either at the trial or in the pre-trial phase, admits that he/she is guilty. The court has no obligation to believe the defendant's confession and is free to assess such evidence upon its own discretion. ${ }^{64}$ This is a considerable difference with respect to the common law systems (England) where the defendant's guilty plea means that the prosecution is released from its duty to bring evidence to trial and the court is obligated to convict. ${ }^{65}$

\footnotetext{
62 Ibid.

63 Ibid.

64 Spencer, J. R., op. cit. Note 3, pp. 594-595.

65 This can be a problem in cases where the defendant pleads guilty for the criminal offence, but disputes some facts of the case, for example the facts that could increase or reduce his/her penalty or could affect the type of criminal offence in question. In those situations, the judge has two options: he/she can hear witnesses or request more evidence or accept the version of the facts that was presented to him/her by the defendant. Ibid, pp. 594-595.
} 


\section{CONCLUDING SUGGESTIONS TO THE CROATIAN LEGISLATURE}

The traditional civil law model of criminal proceedings rests on the inquisitorial principle (Untersuchungsgrundsatz) which prescribes the duty of the court to establish the relevant facts of the case. This means that the defendant's guilt should always be established by evidence. All of the analysed systems that cherish this principle have nevertheless created some alternative or less strict approaches to fact-finding, which usually rest on the idea of consensual justice. Among these countries, Austria has remained most faithful to the inquisitorial principle (with diversion as an exception), while Germany, France and Italy have legalised and regulated some types of agreements between parties, albeit with different approaches to the scope of negotiations, rights of victims, stages of proceedings where the negotiations may take place and the level of court activity during the negotiations and after the reach of the agreement. However, all of these consensual proceedings have a common denominator: whenever a court becomes involved in a consensual procedure, its role is never reduced to a ritualistic one. From the perspective of constitutional division of powers, it is inappropriate to engage judiciary in a substantively meaningless procedure which is nothing more than an homage to an agreement between the parties or to a proposal made by one of them. Moreover, as shown by the English law, the prominence of judiciary in the consensual proceedings is not a civil law peculiarity, but also a feature of common law systems: the sentencing powers remain firmly in the hands of the court, which is obliged to respect the law instead of some mutually brokered deal on a sentence.

Having this in mind, it is surprising that the Croatian legislator has decided to establish a system in which, according to Art. 417.a (6) and (7) of the Code of Criminal Procedure, the court may not fully reject a plea bargain offered by the state prosecutor during the main hearing if the defendant confesses to the indictment. This is surely an example of a contractual approach to the effects of a confession, and, as such, it is rather ambiguous from the constitutional viewpoint. In fact, such provisions do not naturally and logically fit into the Croatian system of criminal justice, which is still based on the Untersuchungsgrundsatz and, accordingly, judge-dominated both in the procedural and substantive respect. The fact that the Croatian criminal courts are obliged to examine the confession in terms of its truthfulness clearly shows that it is considered as a piece of evidence rather than a guilty plea. It thus derives that the trial court should be allowed to evaluate the aggravating circumstances accordingly and, in doing so, be bound only by the law, and not by any sort of sentence-related proposals of the involved parties, especially as these can be a result of unregulated negotiations between the parties disregarding the interests of the victim and the constitutionally prescribed role of the judiciary. In our view, these provisions should be abolished in the course of a comprehensive reform of various forms of consensual procedures which are currently excessive in number and inconsistent in the Croatian criminal legislation. Of course, this does not mean that each and every consensual element of the Croatian criminal procedure should be abandoned, but whatever approach is taken, it should be borne in mind that none of the analysed countries provides for a deal between the parties at the mean hearing in a criminal case which would effectively strip the court of its key powers. The quest for a better, healthier and constitutionally aligned legislative framework in Croatia could be based on German, French or Italian model. To sum up, the court should be allowed either to determine the boundaries of negotiation 
before they take place or, otherwise, to control if the proposed sanction is in accordance with the facts of the case and the purpose of sanctioning, including the right to reject the proposal.

\section{BIBLIOGRAPHY}

1. Coscas-Williams, B., Alberstain, M.: A Patchwork of doors: accelerated proceedings in continental criminal justice systems, New Criminal Law Review, vol. 22, No. 4, fall 2019, pp. 585-617.

2. Dervieux, V.,The French system, in European Criminal Procedures, (eds. Delmas-Marty, M., Spencer, J.R.) Cambridge University Press, 2006, pp. 218-292.

3. Đurđević, Rekonstrukcija, judicijalizacija, konstitucionalizacija, europeizacija hrvatskog kaznenog postupka V. novelom ZKP/08: prvi dio?, HLJKPP, No 2, 2013, pp. 335-342.

4. Frommann, M., Regulating Plea-bargaining in Germany: Can the Italian Approach Serve as a Model to Guarantee the Independence of German Judges?, Comparative law, Hanse Law Review, vol. 5, No, 1, pp. 197-220.

5. Gierhake, K., Zur Begründung des Öffentlichkeitsgrundsatzes im Strafverfahren, JuristenZeitung No. 21, November 2013, pp. 1000-1038.

6. Hodgson, J., Guilty Pleas and the Changing Role of the Prosecutor in French Criminal Justice, Warwick School of Law Research Paper, No. 2010/15, pp. 398-426.

7. Kirchbacher in Fuchs, H., Ratz, E. (eds.), Wiener Kommentar zur Strafprozessordnung, 88. Ed., MANZ, 2009.

8. Krapac, D. i suradnici, Kazneno procesno pravo, Prva knjiga institucije, Narodne novine, Zagreb, 2015.

9. Krstulović, A., Nagodbe stranaka u suvremenom kaznenom postupku, Hrvatsko udruženje za kaznene znanosti i praksu-MUP RH, Zagreb, 2007.

10. Krehl, Karlsruher Kommentar/StPO zur Strafprozessordnung: StPO mit GVG, EGGVG und EMRK, C.H. BECK, 8. Aufl., 2019.

11. Ljubanović, V., Novokmet, A., Tomičić, Z., Kazneno procesno pravo - izabrana poglavlja, PRAVOS, Osijek, 2019.

12. McPeake, R., Criminal Litigation and Sentencing, Oxford, 23the Edition, 2011.

13. Ormedor, D, Perry, D. (eds.), Blackstone's Criminal Practice 2018, Oxfords University Press, UK, 2018.

14. Perrodet, A., The Italian System, in Delmas-Marty, M., Spencer, J.R. (eds.) European Criminal Procedures, Cambridge University Press, Cambridge, 2006, pp. 348-415.

15. Richard Nobles \& David Schiff, The Supervision of Guilty Pleas by the Court of Appeal of England and Wales - Workable Relationships and Tragic Choices, Criminal Law Forum, volume 31, 2020, p. 513-552.

16. Ruggeri, S., Audi Alteram Partem in Criminal Proceedings, Towards a Participatory Understanding of Criminal Justice in Europe and Latin America, Springer, 2017.

17. Ruggieri, F., Marcolini, S., Italy in Ligeti, K. (ed.) Toward a Prosecutor for European Union, volume: 1: A comparative Analysis, London: Hart Publishing, 2013, pp. 368-403.

18. Soubise, L., Guilty Pleas in an Inquisitorial Setting - an Empirical Study of France (September 2018). Journal of Law and Society, Cardiff University Law School, Vol. 45, Issue 3, 2018, pp.

19. Specer, J. R., Evidence, in European Criminal Procedures (eds. Delmas_marty, M., Spencer, J.R.), Cambridge University Press, Cambridge2006, pp. 594-641. 
20. Tomašević, G., Kazneno procesno pravo, Opći dio: Temeljni pojmovi, Pravni fakultet Sveučilišta u Splitu, Split, 2011.

21. Tricot, J., France in Toward a Prosecutor for the European Union, A comparative Analysis (ed. Katalin Ligeti), London: Hart Publishing, vol. 1, 2013, pp. 222-263.

\section{LIST OF REGULATIONS AND ACTS}

1. Strafprozeßordnung (StPO) as published on 7 April 1987 (Official Gazette I, p. 1074, 1319), last amended by Article 49 of the Act from 21 December 2020 (Official Gazette I, p. 3096).

2. Strafprozessordnung (StPO) 1975, BGBl. Nr. 631/1975 (WV), latest amendment BGBl. I Nr. 24/2020.

3. Code de procédure pénale Code de procedure penale, Version en vigueur au 08 décembre 2020, https:// www.legifrance.gouv.fr/codes/texte_lc/LEGITEXT000006071154/. Accessed 13 January 2021.

4. Codice di procedura penale, Aggiornato al D.L. 17 marzo 2020, n. 18. https://www.altalex.com/documents/codici-altalex/2014/10/30/codice-di-procedura-penale. Accessed 13 January 2021.

5. Croatian Code of Criminal Procedure (C-CCP), Official Gazette (Narodne novine), no. 152/08, 76/09, 80/11, 91/12 - Decision and Ruling of the Constitutional Court of the Republic of Croatia, 143/12, 56/13, 145/13, 152/14, 70/17, and 126/19. 


\section{PRIZNANJE OPTUŽENIKA NA GLAVNOJ RASPRAVI U HRVATSKOJ I POREDBENOPRAVNIM SUSTAVIMA: SAMO JOŠ JEDAN DOKAZ, PRIZNANJE KRIVNJE ILI PREŠUTNI SPORAZUM?}

\section{Sažetak}

Učinci okrivljenikova priznanja nisu jednaki u svim pravnim poredcima. U kontinentalnim pravnim sustavima, priznanje krivnje najčešće se tretira kao i svaki drugi dokaz, dok u common law sustavima istinitost okrivljenikova priznanja sud ne propituje. Međutim, to načelno razlikovanje ne vrijedi uvijek i svugdje. U hrvatskom pravu, ako se optuženik za kazneno djelo za koje je propisana novčana kazna ili kazna zatvora do pet godina na raspravi očituje krivim u odnosu na sve točke optužbe i suglasi sa sankcijom koju je predložio državni odvjetnik, sud mu u presudi ne smije izreći strožu kaznu od predložene. Takvo zakonsko rješenje može potaknuti prešutne dogovore i neregulirane pregovore između stranaka nakon što je rasprava već započela, a nije jasno je li to zakonodavac imao na umu kada je donosio ovu odredbu. Kako bi navedenu problematiku istražili iz šire perspektive, autori su u radu analizirali hrvatsko, njemačko, austrijsko, francusko, talijansko i englesko pravo, s naglaskom na položaju optuženika nakon priznanja na raspravi, učincima priznanja, ulozi suda u daljnjem postupku i pravima žrtve. Nakon usporedne analize, autori iznose svoje mišljenje o trenutačnom zakonskom rješenju u Hrvatskoj, a posebno o čl. 417.a st. 6. i 7. Zakona o kaznenom postupku i daju prijedlog zakonskih izmjena.

Ključne riječi: $\quad$ priznanje, guilty plea, glavna rasprava, konsenzualnost u kaznenom postupku, kazneni postupak

\section{(c) (1) (8)}

This work is licensed under a Creative Commons

Attribution-NonCommercial 4.0 International License.

Dr. sc. Igor Martinović, izvanredni profesor Pravnog fakulteta Sveučilišta u Rijeci, Hahlić 6, 51000 Rijeka. E-adresa: imartinovic@ pravri.hr. ORCID: https://orcid.org/0000-0002-7648-2443.

* Dr. sc. Ivana Radić, poslijedoktorandica Pravnog fakulteta Sveučilišta u Splitu, Domovinskog rata 8, 21000 Split. E-adresa: ivana. radic@pravst.hr. ORCID: https://orcid.org/0000-0003-4946-6437. 